Pak. j. sci. ind. res. Ser. B: biol. sci. 2017 60(2) 102-111

\title{
Accumulation of Heavy Metals by Living and Dead Bacteria as Biosorbents: Isolated from Waste Soil
}

\author{
Iqra Batool ${ }^{\mathrm{a}}$, Saiqa Andleeb ${ }^{\mathrm{a} *}$, Shaukat Ali ${ }^{\mathrm{b}}$, Kalsoom Akhtar ${ }^{\mathrm{c}}$ and Nazish Mazhar Ali ${ }^{\mathrm{d}}$ \\ ${ }^{a}$ Microbial Biotechnology Laboratory, Department of Zoology, University of Azad Jammu and Kashmir, \\ Muzaffarabad-3100, Pakistan \\ ${ }^{\mathrm{b}}$ Toxicology Laboratory, Department of Zoology, University of Azad Jammu and Kashmir, \\ Muzaffarabad-3100, Pakistan \\ 'Department of Chemistry, University of Azad Jammu and Kashmir, Muzaffarabad-13100, Pakistan \\ ${ }^{\mathrm{d}}$ Microbiology Laboratory, Department of Zoology, Government College University, Lahore, Pakistan
}

(received February 3, 2016; revised June 22, 2016; accepted July 12, 2016)

\begin{abstract}
In the present study Enterococcus luteus, Escherichia coli and Staphylococcus aureus have been used for biosorption of cadmium and chromium from aqueous solution of various concentrations. Bacteria were isolated from waste soil and identified through various morphological features, biochemical tests, and staining procedure. Biosorption capacity (both dead and live biomass) was observed through broth technique and absorbance values were measured using atomic absorbance spectrophotometer. Different parameters were optimised for metal biosorption, including incubation periods $(24,48,72$ and $96 \mathrm{~h})$ and $\mathrm{pH}(4,6,7,8,9$, and 10$)$ at $37^{\circ} \mathrm{C}$. Agar well and agar disc diffusion methods were used for resistogram and antibiogram analysis. Through agar well diffusion method, $S$. aureus showed complete resistance against all concentrations of chromium and cadmium (50 to $300 \mu \mathrm{g} / \mathrm{mL})$. E. luteus showed resistance on $50 \mu \mathrm{g} / \mathrm{mL}$ and $100 \mu \mathrm{g} / \mathrm{mL}$ of both metals while $E$. coli exhibited resistance against all cadmium concentrations ( 50 to $300 \mu \mathrm{g} / \mathrm{mL}$ ) while sensitivity was observed in case of chromium $(12.0 \pm 0.0 \mathrm{~mm}$ to $24.0 \pm 0.0 \mathrm{~mm})$. Through broth method, E. luteus showed good cadmium absorbance capacity at acidic $\mathrm{pH} 4$ and 6, E. coli at $\mathrm{pH} \mathrm{4,6}$ and 7 and $S$. aureus at $\mathrm{pH} \mathrm{6,7}$ and 8. In case of chromium, S. aureus showed maximum absorbance at $\mathrm{pH} 6 ;$ E. coli at $\mathrm{pH} 7$ and 8 and E. luteus showed minimum absorbance for chromium at $\mathrm{pH}$ 6 and 8 . All bacterial isolates showed maximum biosorption of both metals after $24 \mathrm{~h}$ of incubation. Results suggested that $\mathrm{pH} 6$ and incubation period $24 \mathrm{~h}$ could be better for biosorption of cadmium and chromium removal. Dead biomass of $E$. coli and $S$. aureus was more efficient for cadmium removal while both dead and live biomass (E. luteus, E. coli and $S$. aureus) have potential for chromium removal. These microbes could be used as potential source of heavy metal biosorbent, biosorbent
\end{abstract}

Keywords: heavy metals, resistogram analysis, antibiogram assay, biosortent

\section{Introduction}

In developing countries like Pakistan, the risk of heavy metal exposure to the environment is increasing day by day. Such heavy metals can cause impact on human health and are toxic to animals too (Tokar et al., 2011; Jomova and Valko, 2011). A considerable amount of heavy metals is present in waste water coming from different sources, i.e., electroplating, paint, leather, metal and tanning industries. Heavy metals are removed from the waste water through the process of biosorption and bioremediation using microorganisms and it has been proved as a very cost effective and environmental friendly process (Elekwachi et al., 2014; Joshi et al., 2011). Biosorption is a process, in which there may be some chemical relationships between the metals and

*Author for correspondence; E-mail:drsaiqa@gmail.com microbes used (Shumate and Stranberg, 1985). Significance of biosorption process over conventionally used method is that it is cost effective, very efficient and shows decreased chemical and biological waste products. Recovery of biomass used and possibility of metal recovery is also possible by biosorption (Kratochvil and Volesky, 1998). Biosorbents are a large subclass of low-cost adsorbents that can be subdivided into biomass (dead or living), agricultural wastes, and industrial solid wastes (Bhatnagar and Minocha, 2006). Dead biomass has been utilised by many researchers as a functional biosorbent to remove different pollutants ( $\mathrm{Li}$ et al., 2010; Saraswat and Rai, 2010). Dead biomass is more readily desorbed than its living counterpart. Living biomasses including fungi (Kumar, 2014; Ismael et al., 2004; Fu and Viraghavan, 2002; 2000), algae (Navarro et al., 2012; Bishnoi and Pant, 2004), actinomycetes 
(Solecka et al., 2012; Fu and Virarghavan, 2002; 2000) and other microbial cultures with different strains (Kocberber and Donmez, 2007) were also used as lowcost biosorbents. Bacterial species like Bacillus has been identified as having a high potential of metal absorption and so it has been commercially used in biosorbent material preparation (Ghaima et al., 2013; Singh et al., 2012; Brierley, 1990).

Cadmium and chromium have highly deleterious effects on plants, animals as well as on human life. Cadmium is hazardous and highly toxic metal for environment and to human beings. This biologically non-essential element accumulates in body, especially in kidneys, liver, lung and brain. It can induce several toxic effects, depending on the concentration and exposure time. Cadmium has been linked to Alzheimer's disease (AD) as a probable risk factor (Meleleo et al., 2010). Cadmium is dangerous to virtually all vital systems in the animal body. On the other hand extreme usage of chromium supplements can cause stomach problems and hypoglycemia. Too much chromium uptake can also cause various injuries like liver, kidneys, and nerve problems, and it also causes irregular heart rhythm. Major sources of cadmium and chromium include refined foods, water containing foods, pipes of water, vegetables and fruits, coffee, tea, burning coal and cigarettes (Costa, 2003).

Understanding the problems occurring due to heavy metals exposure and their degradation by biological means is necessary. As according to the above discussion and literature review, it is an urgent need of time to explore different microbial strains as biosorbent to remove heavy metals from different sources. Therefore, this study was planned to isolate and identify the bacteria from waste sources which could be used to purify the contaminated water.

\section{Materials and Methods}

Sample collection. The contaminated soil samples viz., slaughter house waste, dairy waste, and household were collected in sterilised containers from different localities (Lower Chellah and Lower Plate: near workstation of automobiles) of Muzaffarabad, Azad Jammu and Kashmir, Pakistan. All samples were collected in triplicate.

Isolation and culturing of bacteria. Contaminated soil samples for isolation of bacterial strains were spread on nutrient agar and MacConkey agar media plates (NAM; Oxoid $\mathrm{CMOO}_{3}, \mathrm{MAM}$; Oxoid CM115), incubated at $37^{\circ} \mathrm{C}$ in incubator up to colony appearance. After $24 \mathrm{~h}$ incubation, single colony was picked up, streaked into nutrient broth medium (NBM; Oxoid $\mathrm{CMI}$ ), placed in shaking incubator at $37^{\circ} \mathrm{C}$ for $24 \mathrm{~h}$. Next day, the mixed cultures were again purified by quadrant streaking on nutrient agar and MacConkey agar plates. The pure culture was grown in nutrient broth medium for overnight at $37^{\circ} \mathrm{C}$. Next day, bacteria were preserved in $60 \%$ glycerol and then placed at -20 ${ }^{\circ} \mathrm{C}$ for further processing.

Identification of bacteria. Bacterial species were identified on the basis of colony morphology: Gram's staining and using biochemical tests (Cheesbrough, 2002; Collins et al., 1999; 1989). Further clarification and identification of all isolated bacteria were carried out at Department of Zoology, Government College University, Lahore, Pakistan.

Preparation of heavy metal concentrations. Chromium (Cr) and cadmium (Cd) heavy metals were used for biosorption assay. For cadmium $\mathrm{Cd}$ (II) and chromium $\mathrm{Cr}(\mathrm{IV})$ solutions $\mathrm{CdCl}_{2}$ and $\mathrm{K}_{2} \mathrm{Cr}_{2} \mathrm{O}_{7}$ salts were used. For each metal, a range of 50, 100, 150, 200, 250 and $300 \mu \mathrm{g} / \mathrm{mL}$ were obtained. The metal solutions were prepared in sterilised distilled water so as to prevent any chances of contamination.

Resistogram analysis. Heavy metal resistance study for microbial isolates was performed using agar well diffusion method (Jagessar et al., 2008) with increasing concentrations of $\mathrm{Cr}$ and $\mathrm{Cd}$ ranging from 50 to 300 . Nutrient agar (Oxide: $\mathrm{CMOO}_{3}$ ) and nutrient broth media (Oxide: CM1) were used for bacterial culture. The $\mathrm{pH}$ of media was adjusted to a final $\mathrm{pH} 7$ by using sodium hydroxide. The microorganisms were activated by inoculating a loop full of strain in $25 \mathrm{~mL}$ of nutrient broth medium and incubated at $37^{\circ} \mathrm{C}$ on a rotatory shaker for $24 \mathrm{~h}$. The overnight culture was mixed with freshly prepared nutrient agar medium (NAM) at 45 ${ }^{\circ} \mathrm{C}$ and was poured into the sterilised petri dishes. All petri dishes were kept at room temperature in laminar flow for solidification. In each plate, 3 wells of $5 \mathrm{~mm}$ diameter were made using a $1 \mathrm{~mL}$ of sterilised micropipette tip and sterilised needle was used for the removal of agar plug. Approximately $30 \mu \mathrm{L}$ of each heavy metal concentration were placed in each prepared well and placed at $37^{\circ} \mathrm{C}$ for $24-48 \mathrm{~h}$. Microbial growth was determined by measuring the diameter of zone of inhibition after $24 \mathrm{~h}$ (Seeley et al., 2001). Diameter of the clear zones (if greater than $1 \mathrm{~mm}$ ) around each well was measured with the help of scale (Hammer et al., 
1999). The results of the sensitivity test were expressed as (0) for no sensitivity, * ( $1-5 \mathrm{~mm})$ for low sensitivity, $* *(>5-10 \mathrm{~mm})$ for moderate sensitivity and $* * *(>10-$ $25 \mathrm{~mm}$ ) for high sensitivity. The bacterial species having maximum resistance to these metals were selected for further study.

Antibiogram analysis . Sensitivity of antibiotics against test microbial strains was assessed through agar disc diffusion method (Prescott et al., 1999). This method is called antibiogram assay. Sensitivity was predicted with degree of clear zone of microbial growth inhibition surrounding the disc. The potency of standard antibiotics has been indicated as Ciprofloxacin (CIP; $5 \mu \mathrm{g}$ ), Ampicillin (AMP; $10 \mu \mathrm{g}$ ), Penicillin G $(\mathrm{P} ; 10 \mu \mathrm{g})$, Neomycin $(\mathrm{N} ; 10 \mu \mathrm{g})$, Vancomycin (VA; $30 \mu \mathrm{g})$, Erythromycin $(\mathrm{E} ; 15 \mu \mathrm{g})$, Norfloxacin (NOR; $10 \mu \mathrm{g}$ ), Tetracycline (TE; $30 \mu \mathrm{g})$, Gentamicin (CN; $10 \mu \mathrm{g}$ ), Oxytetracycline (OT; $30 \mu \mathrm{g})$, Streptomycin (S; $10 \mu \mathrm{g})$, Chloramphenicol (C; $30 \mu \mathrm{g}$ ), Tobramycin (TOB; 10 $\mu \mathrm{g}$ ), Nalidixic acid (NA; $30 \mu \mathrm{g}$ ), Sulfamethoxazole (SXT; $25 \mu \mathrm{g}$ ) and Kanamycin (K; $30 \mu \mathrm{g}$ ). All discs of antibiotics were purchased and made by Oxoid Company.

Bioaccumulation/biosorption study. In this study, each isolate was cultivated anaerobically in properly labelled test tubes containing nutrient broth medium by incubating the test tubes at $37^{\circ} \mathrm{C}$ in shaking incubator. Five $\mathrm{mL}$ of bacterial suspension (E. luteus, $S$. aureus and E. coli) having dried biomass $(4,11$ and $27 \mathrm{mg})$ was mixed with $1 \mathrm{~mL}$ metal solution in sterilised test tubes which were then covered with aluminum foil and agitated at $150 \mathrm{rpm}$ on a shaking incubator at $37{ }^{\circ} \mathrm{C}$. Biosorption was assayed by exposing the isolates to two different metals i.e., $\mathrm{Cr}(\mathrm{VI})$ and $\mathrm{Cd}(\mathrm{II})$ concentrations. The effects of different parameters like metal ion concentration, $\mathrm{pH}$ and incubation time on the adsorption capacity of each isolate were studied. After incubation, the samples were then centrifuged for $5 \mathrm{~min}$ at $13000 \mathrm{rpm}$ and supernatant was used for the estimation of metal ion concentration using double beam spectrophotometer (Sshimadzu UV 1800). A control was also set containing nutrient broth medium along with metal solution keeping all other conditions same except bacterial culture. Each test was performed in triplicates and their average value was taken as result.

The following parameters on adsorption capacity of isolates were studied:

1. The effect of metal ion concentration was studied using metal concentration ranging from 50-300 $\mu \mathrm{g} / \mathrm{mL}$ for each metal ion.

2. The effect of incubation time of bacterial culture with metal solution was also studied. The incubation time given to the solution was $24 \mathrm{~h}$, 48,72 and $96 \mathrm{~h}$.

3. The effect of $\mathrm{pH} 4,6,7,8$ and 10 was studied and $\mathrm{pH}$ was adjusted by using analytical grade sodium hydroxide and hydrochloric acid.

$\mathrm{Cr}(\mathrm{VI})$ was analysed by diphenylcarbazide method, and Cd(II) by dithizone method. The metal removal efficiency of each strain was calculated by equation 1 .

$$
\text { R. } \%=\left(\mathrm{C}_{\mathrm{i}}-\mathrm{C}_{\mathrm{e}}\right) / \mathrm{C}_{\mathrm{i}} \times 100
$$

Where:

$\mathrm{R}=$ the removal efficiency $(\%), \mathrm{C}_{\mathrm{i}}=$ the initial metal concentration before removal $(\mu \mathrm{g} / \mathrm{mL})$ and $\mathrm{C}_{\mathrm{e}}=$ the final metal concentration after removal $(\mu \mathrm{g} / \mathrm{mL})$ while, the amount of metal adsorption on the bacterial biomass can be calculated by equation 2 .

$$
\mathrm{q}_{\mathrm{eq}}=\left(\mathrm{C}_{\mathrm{o}}-\mathrm{C}_{\mathrm{eq}}\right) \mathrm{V} / \mathrm{M} \ldots \ldots \ldots \ldots \ldots \ldots \ldots \ldots \ldots \ldots \ldots \ldots
$$

Where:

$\mathrm{q}_{\mathrm{eq}}(\mathrm{mg} / \mathrm{g})=$ the metal adsorption capacity, $\mathrm{C}_{\mathrm{o}}(\mathrm{mg} / \mathrm{L})$ $=$ initial metal ion concentration, and $\mathrm{C}_{\mathrm{eq}}=$ final metal ion concentration, respectively. $\mathrm{V}=$ the solution volume and $\mathrm{M}(\mathrm{g})=$ the amount of biosorbent used.

Determination of metal concentration in the supernatant. Atomic absorption spectrophotometer, Perkin Elmer Analyst 300 was used to determine the heavy metal concentration (chromium and cadmium). The wavelength $544 \mathrm{~nm}$ and $545 \mathrm{~nm}$ were used for cadmium and chromium. It was done by using its specific lamp for each metal and at a specific wavelength.

Statistical analysis. Each experiment of resistogram and antibiogram analysis was repeated in triplicates and standard deviation from absolute data was calculated (http://easycalculation.com/statistics/standarddeviation.php).

\section{Results and Discussion}

Isolation and identification of bacteria. Three bacterial isolates such as Enterococcus luteus, Staphylococcus aureus and Escherichia coli were isolated from the contaminated soil samples. These strains were identified through gram's staining and biochemical tests (Table 1). E. luteus indicated urease and catalase positive tests 
while citrate, coagulase, oxidase, indole and nitrate tests were negative. $S$. aureus is gram positive cocci and motile. S. aureus showed catalase, coagulase, citrate, urease, methyl red, nitrate tests positive while oxidase, Voges proskeur tests were negative. Catalase, indole, methyl red, and nitrate tests were positive for $E$. coli while citrate, coagulase, oxidase and urease tests were recorded as negative results. Glucose and lactose fermentation tests were positive for $E$. coli and $S$. aureus whereas, E. luteus indicated non-fermenter of carbohydrates.

Table 1. Identification of bacterial isolates through gram's staining and biochemical tests

\begin{tabular}{llll}
\hline \hline $\begin{array}{l}\text { Biochemical } \\
\text { tests for bacterial }\end{array}$ & $\begin{array}{l}\text { Enterococcus } \\
\text { luteus }\end{array}$ & $\begin{array}{l}\text { Escherichia } \\
\text { coli }\end{array}$ & $\begin{array}{l}\text { Staphylococcus } \\
\text { aureus }\end{array}$ \\
identification & & & \\
\hline Gram staining & $+\mathrm{ve}$ & -ve & $+\mathrm{ve}$ \\
Colony morphology & Coccus & Rod & Coccus \\
Citrate test & -ve & -ve & $+\mathrm{ve}$ \\
Catalase test & $+\mathrm{ve}$ & $+\mathrm{ve}$ & $+\mathrm{ve}$ \\
Coagulase test & $-\mathrm{ve}$ & $-\mathrm{ve}$ & $+\mathrm{ve}$ \\
Indole test & $-\mathrm{ve}$ & $+\mathrm{ve}$ & $-\mathrm{ve}$ \\
Methyl red test & $-\mathrm{ve}$ & $+\mathrm{ve}$ & $+\mathrm{ve}$ \\
Oxidase test & -ve & $-\mathrm{ve}$ & $-\mathrm{ve}$ \\
Urease test & $+\mathrm{ve}$ & $-\mathrm{ve}$ & $+\mathrm{ve}$ \\
Motility test & $-\mathrm{ve}$ & $+\mathrm{ve}$ & $+\mathrm{ve}$ \\
Carbohydrate test & & & \\
(glucose and lactose) & $-\mathrm{ve}$ & +ve & $+\mathrm{ve}$ \\
Nitrate test & $-\mathrm{ve}$ & $+\mathrm{ve}$ & $+\mathrm{ve}$ \\
Voges Proskeur test & $-\mathrm{ve}$ & $-\mathrm{ve}$ & $-\mathrm{ve}$ \\
\hline \hline
\end{tabular}

$+\mathrm{ve}$ and $-\mathrm{ve}$ indicate positive and negative results.

Resistogram analysis. For chromium metal concentrations. In resistogram analysis E. luteus showed resistance against $\mathrm{Cr}(\mathrm{IV})$ metal at $50 \mu \mathrm{g} / \mathrm{mL}$ and 100 $\mu \mathrm{g} / \mathrm{mL}$, but seemed to be sensitive against higher concentrations i.e., 150, 200, 250 and $300 \mu \mathrm{g} / \mathrm{mL}$. Zone of inhibition was measured as $14.0 \pm 0.0 \mathrm{~mm}$ against $150 \mu \mathrm{g} / \mathrm{mL}, 15.0 \pm 0.0 \mathrm{~mm}$ against $200 \mu \mathrm{g} / \mathrm{mL}, 15.0 \pm$ $0.0 \mathrm{~mm}$ against $250 \mu \mathrm{g} / \mathrm{mL}$ and $16.0 \pm 0.0 \mathrm{~mm}$ against $300 \mu \mathrm{g} / \mathrm{mL}$. $S$. aureus showed resistance against all concentrations of $\mathrm{Cr}(\mathrm{IV})$ metal whereas, E. coli showed high sensitivity against all concentrations of $\mathrm{Cr}(\mathrm{IV})$ metal. Zone of inhibition measured against each concentration was recorded as; $12.0 \pm 0.0 \mathrm{~mm}$ against $50 \mu \mathrm{g} / \mathrm{mL}, 15.0 \pm 0.0 \mathrm{~mm}$ against $100 \mu \mathrm{g} / \mathrm{mL}, 19.0 \pm$ $0.0 \mathrm{~mm}$ against $150 \mu \mathrm{g} / \mathrm{mL}, 20.0 \pm 0.0 \mathrm{~mm}$ against 200 $\mu \mathrm{g} / \mathrm{mL}, 20.0 \pm 0.0 \mathrm{~mm}$ against $250 \mu \mathrm{g} / \mathrm{mL}$ and $24.0 \pm$ $0.0 \mathrm{~mm}$ against $300 \mu \mathrm{g} / \mathrm{mL}$. In each case it was observed that sensitivity increased with increase in metal concentrations (Table 2).

For Cd(II) metal concentrations. E. luteus showed resistance against four $\mathrm{Cd}$ (II) concentrations such as $50,100,250$, and $300 \mu \mathrm{g} / \mathrm{mL}$. While against other two concentrations sensitivity was observed and the zone of inhibition was measured as $15.0 \pm 0.0 \mathrm{~mm}$ against $150 \mu \mathrm{g} / \mathrm{mL}$ and $12.0 \pm 0.0 \mathrm{~mm}$ against $200 \mu \mathrm{g} / \mathrm{mL} . S$. aureus and $E$. coli seemed to be fully resistant against all concentrations of Cd(II) (Table 3 ).

Antibiogram analysis. In case of antibiogram analysis E. luteus showed sensitivity against all antibiotics. The maximum zones of inhibition were measured as 28.0 $\pm 0.0 \mathrm{~mm}$ against $\mathrm{CIP}, 13.0 \pm 0.0 \mathrm{~mm}$ against $\mathrm{N}, 17.0$ $\pm 0.0 \mathrm{~mm}$ against $\mathrm{VA}, 21.0 \pm 0.0 \mathrm{~mm}$ against $\mathrm{E}, 19.0$ $\pm 0.0 \mathrm{~mm}$ against $\mathrm{NOR}, 14.0 \pm 0.0 \mathrm{~mm}$ against $\mathrm{CN}$, $13.0 \pm 0.0 \mathrm{~mm}$ against $\mathrm{S}, 17.0 \pm 0.0$ against $\mathrm{NA}, 18.0$ $\pm 0.0 \mathrm{~mm}$ against $\mathrm{C}$, and $12.0 \pm 0.0 \mathrm{~mm}$ against $\mathrm{OT}$

Table 2. Resistogram analysis of chromium concentrations against bacterial isolates

\begin{tabular}{llllllll}
\hline \hline & \multicolumn{6}{c}{ Chromium metal concentrations } \\
\cline { 2 - 5 } $\begin{array}{l}\text { Microbes } \\
\text { used }\end{array}$ & 50 & 100 & 150 & 200 & 250 & 300 & \\
\cline { 2 - 6 } & \multicolumn{7}{c}{$(\mu \mathrm{g} / \mathrm{mL})$} \\
Zone of inhibition in mm $(\mathrm{M} \pm \mathrm{SD})$ & & \\
\hline E. luteus & $\mathrm{R}$ & $\mathrm{R}$ & $14.0 \pm$ & $15.0 \pm$ & $15.0 \pm$ & $16.0 \pm$ & 7 \\
S. aureus & $\mathrm{R}$ & $\mathrm{R}$ & $\mathrm{R}$ & $\mathrm{R}$ & $\mathrm{R}$ & $\mathrm{R}$ & 7 \\
E. coli & $12.0 \pm$ & $15.0 \pm$ & $19.0 \pm$ & $20.0 \pm$ & $20.0 \pm$ & $24.0 \pm$ & 7 \\
& 0.0 & 0.0 & 0.0 & 0.0 & 0.0 & 0.0 & \\
\hline \hline
\end{tabular}

Growth inhibition were expressed as (0) for no sensitivity, (1- $5 \mathrm{~mm}$ ) for low sensitivity, $(>5-10 \mathrm{~mm})$ for moderate sensitivity and ( $>10-25 \mathrm{~mm})$ for high sensitivity. R for resistance; $(\mathrm{M} \pm \mathrm{SD})$ Mean \pm Standard deviation.

Table 3. Resistogram analysis of cadmium concentrations against bacterial isolates

\begin{tabular}{|c|c|c|c|c|c|c|c|}
\hline \multirow{4}{*}{$\begin{array}{l}\text { Microbes } \\
\text { used }\end{array}$} & \multicolumn{6}{|c|}{ Cadmium metal concentrations } & \multirow{4}{*}{$\mathrm{pH}$} \\
\hline & 50 & 100 & 150 & 200 & 250 & 300 & \\
\hline & \multicolumn{6}{|c|}{$(\mu \mathrm{g} / \mathrm{mL})$} & \\
\hline & \multicolumn{6}{|c|}{ Zone of inhibition in $\mathrm{mm}(\mathrm{M} \pm \mathrm{SD})$} & \\
\hline E. luteus & $\mathrm{R}$ & $\mathrm{R}$ & $\begin{array}{l}15.0 \pm \\
0.0\end{array}$ & $\begin{array}{l}12.0 \pm \\
0.0\end{array}$ & $\mathrm{R}$ & $\mathrm{R}$ & 7 \\
\hline S. aureus & $\mathrm{R}$ & $\mathrm{R}$ & $\mathrm{R}$ & $\mathrm{R}$ & $\mathrm{R}$ & $\mathrm{R}$ & 7 \\
\hline E. coli & $\mathrm{R}$ & $\mathrm{R}$ & $\mathrm{R}$ & $\mathrm{R}$ & $\mathrm{R}$ & $\mathrm{R}$ & 7 \\
\hline
\end{tabular}

Growth inhibition were expressed as (0) for no sensitivity, (1- $5 \mathrm{~mm})$ for low sensitivity, $(>5-10 \mathrm{~mm})$ for moderate sensitivity and ( $>10-5 \mathrm{~mm})$ for high sensitivity. $R$ for resistance; $(\mathrm{M} \pm \mathrm{SD})$ Mean \pm Standard deviation. 
(Table 4). S. aureus also seemed to be sensitive against most of the antibiotics. It showed resistance against $P$, AMP, and SXT. Sensitivity was recorded as $20.0 \pm 0.0$ $\mathrm{mm}$ against $\mathrm{CIP}, 11.0 \pm 0.0 \mathrm{~mm}$ against $\mathrm{VA}, 17.0 \pm 0.0$ $\mathrm{mm}$ against $\mathrm{E}, 22.0 \pm 0.0 \mathrm{~mm}$ against $\mathrm{NOR}, 20.0 \pm 0.0$ $\mathrm{mm}$ against $\mathrm{CS}, 14.0 \pm 0.0 \mathrm{~mm}$ against $\mathrm{S}, 13.0 \pm 0.0$ $\mathrm{mm}$ against $\mathrm{NA}$, and $11.0 \pm 0.0 \mathrm{~mm}$ against $\mathrm{C}$ (Table 4). E. coli showed resistance against P, TET, AMP, OT and SXT while, sensitivity was observed as $19.0 \pm 0.0$ $\mathrm{mm}$ against $\mathrm{CIP}, 14.0 \pm 0.0 \mathrm{~mm}$ against $\mathrm{N}, 23.0 \pm 0.0$ $\mathrm{mm}$ against $\mathrm{E}, 23.0 \pm 0.0 \mathrm{~mm}$ against $\mathrm{NOR}, 17.0 \pm 0.0$ $\mathrm{mm}$ against $\mathrm{CN}, 19.0 \pm 0.0 \mathrm{~mm}$ against $\mathrm{S}$, and $11.0 \pm$ $0.0 \mathrm{~mm}$ against NA (Table 4 ).

\section{Biosorption of $\mathrm{Cd}(\mathrm{II})$ and $\mathrm{Cr}(\mathrm{IV})$ at various $\mathrm{pH}$ and} incubation periods. Metal absorbance capacity of microbes is expressed in graphical way. The lines in graph show the amount of metal left in medium after microbial activity. Higher lines show much amount of metal left in medium and lower lines show less amount left while, no lines show zero \% metal left behind, meaning that all the metals have been absorbed by the microbes. Different colours of lines are shown to express different concentrations of metals like dark blue colour used for $50 \mu \mathrm{g} / \mathrm{mL}$, red for $100 \mu \mathrm{g} / \mathrm{mL}$, green for 150 $\mu \mathrm{g} / \mathrm{mL}$, purple for $200 \mu \mathrm{g} / \mathrm{mL}$, sky blue for $250 \mu \mathrm{g} / \mathrm{mL}$ and for $300 \mu \mathrm{g} / \mathrm{mL}$ orange.

Cd(II) bioaccumulation by $\boldsymbol{E}$. luteus. With the decrease in $\mathrm{pH}$ up to acidic $\mathrm{pH} 4$, E. luteus showed $100 \%$ absorbance of $\mathrm{Cd}(\mathrm{II})$ on all incubatory periods; 24,48 , 72, and 96 h (Fig. 1). Metal concentration seemed to had no effect on absorbance. At the $\mathrm{pH} \mathrm{6,} \mathrm{E.} \mathrm{luteus}$ showed decreased absorbance of Cd(II) after $24 \mathrm{~h}$ of incubation but after 48, 72, and $96 \mathrm{~h}$ of incubation, $E$. luteus showed $100 \%$ absorbance capacity. Even at each concentration, absorbance capacity remained constant (Fig. 1 ). At pH 7, Cd(II) absorbance activity was little decreased after $24 \mathrm{~h}$ of incubation at $37{ }^{\circ} \mathrm{C}$ but with increase in incubatory periods i.e., after 48, 72 and $96 \mathrm{~h}$ the absorbance capacity of microbe decreased gradually (Fig. 1). Side by side the increase in metal concentration seemed to have negative impact on absorbance, as the absorbance decreased with increase in metal concentration. At pH 8 and 10, E. luteus showed absorbance which increased gradually with increase in incubation period. Maximum absorbance at $\mathrm{pH} 10$ was observed after $96 \mathrm{~h}$ of incubation (Fig. 1).

Cd(II) bioaccumulation by $\boldsymbol{E}$. coli. At acidic $\mathrm{pH} 4$ and 6 , microbe $E$. coli showed very good absorbance activity. The metal was absorbed $100 \%$ at each concentration level and incubatory period. Metal concentration even did not affect the absorbance capacity of E. coli (Fig. 1). At pH 7 after 24 and 48 h, E. coli showed maximum absorbance, and even $100 \%$ at 300 $\mu \mathrm{g} / \mathrm{mL}$. While this activity decreased after $72 \mathrm{~h}$ and same results were observed after $96 \mathrm{~h}$ as well (Fig. 1). At $\mathrm{pH} 8$, E. coli showed good absorbance activity after 72 and $96 \mathrm{~h}$ of incubation except $300 \mu \mathrm{g} / \mathrm{mL}$ and with increase in incubation this activity also increased. $E$. coli showed absorbance of $\mathrm{Cd}(\mathrm{II})$ at $\mathrm{pH} 10$, which increased with increase in incubatory periods (Fig. 1).

Cd(II) bioaccumulation by $\boldsymbol{S}$. aureus. Staphylococcus aureus showed good and complete absorbance activity after $24 \mathrm{~h}$, at $\mathrm{pH} 6,7$ and 8. While increase in concentration had no effect on absorbance capacity of

Table 4. Sensitivity test of selected standard antibiotics against bacterial strains

\begin{tabular}{|c|c|c|c|c|c|c|c|c|c|c|c|c|c|c|c|c|}
\hline \multirow{3}{*}{$\begin{array}{l}\text { bacterial } \\
\text { pathogens }\end{array}$} & \multicolumn{16}{|c|}{ Antibiotics } \\
\hline & CIP & $\mathrm{P}$ & TET & $\mathrm{N}$ & VA & $\mathrm{E}$ & NOR & AMP & $\mathrm{CN}$ & $\mathrm{S}$ & NA & TOB & $\mathrm{K}$ & $\mathrm{C}$ & OT & SXT \\
\hline & & & & & \multicolumn{12}{|c|}{ Zone of inhibition in $\mathrm{mm}(\mathrm{Mean} \pm \mathrm{SD})$} \\
\hline \multirow[t]{2}{*}{ E. luteus } & $28.0 \pm$ & $3.0 \pm$ & $3.0 \pm$ & $13.0 \pm$ & $17.0 \pm$ & $21.0 \pm$ & $19.0 \pm$ & $5.0 \pm$ & $14.0 \pm$ & $13.0 \pm$ & $17.0 \pm$ & $2.0 \pm$ & $8.0 \pm$ & $18.0 \pm$ & $12.0 \pm$ & $10.0 \pm$ \\
\hline & 0.0 & 0.0 & 0.0 & 0.0 & 0.0 & 0.0 & 0.0 & 0.0 & 0.0 & 0.0 & 0.0 & 0.0 & 0.0 & 0.0 & 0.0 & 0.0 \\
\hline \multirow[t]{2}{*}{ S. aureus } & $20.0 \pm$ & $\mathrm{R}$ & $4.0 \pm$ & $10.0 \pm$ & $11.0 \pm$ & $17.0 \pm$ & $22.0 \pm$ & $\mathrm{R}$ & $20.0 \pm$ & $14.0 \pm$ & $13.0 \pm$ & $6.0 \pm$ & $10.0 \pm$ & $11.0 \pm$ & $5.0 \pm$ & $\mathrm{R}$ \\
\hline & 0.0 & 0.0 & 0.0 & 0.0 & 0.0 & 0.0 & 0.0 & & 0.0 & 0.0 & 0.0 & 0.0 & 0.0 & 0.0 & 0.0 & \\
\hline \multirow[t]{2}{*}{ E. coli } & $19.0 \pm$ & $\mathrm{R}$ & $\mathrm{R}$ & $14.0 \pm$ & $6.0 \pm$ & $23.0 \pm$ & $23.0 \pm$ & $\mathrm{R}$ & $17.0 \pm$ & $19.0 \pm$ & $11.0 \pm$ & $2.0 \pm$ & $7.0 \pm$ & $7.0 \pm$ & $\mathrm{R}$ & $\mathrm{R}$ \\
\hline & 0.0 & & & 0.0 & 0.0 & 0.0 & 0.0 & & & 0.0 & 0.0 & 0.0 & 0.0 & 0.0 & & \\
\hline
\end{tabular}

The results of the sensitivity tests were expressed as (0) for no sensitivity, (1- $10 \mathrm{~mm}$ ) for low sensitivity, (11-19 $\mathrm{mm})$ for moderate sensitivity and $(20-35 \mathrm{~mm})$ for high sensitivity. $\mathrm{R}$ indicates resistance. CIP (ciproflaxin); $\mathrm{P}=$ pencillin $\mathrm{G}$; TE =tetracycline; $\mathrm{N}$ =neomycin; $\mathrm{VA}=$ vancomycin; $\mathrm{E}=$ erytheromycin; $\mathrm{NOR}=$ norflaxin; $\mathrm{AMP}=$ ampicillin; $\mathrm{CN}$ getamycin; $\mathrm{S}$ =streptomycin; NA =nalidixic acid; TOB =tobramycin, $\mathrm{K}=$ kanamycin; $\mathrm{C}=$ chloramphenicol; $\mathrm{OT}=$ oxytetracyclin, $\mathrm{SXT}$ $=$ sulfmethoxyzole. 


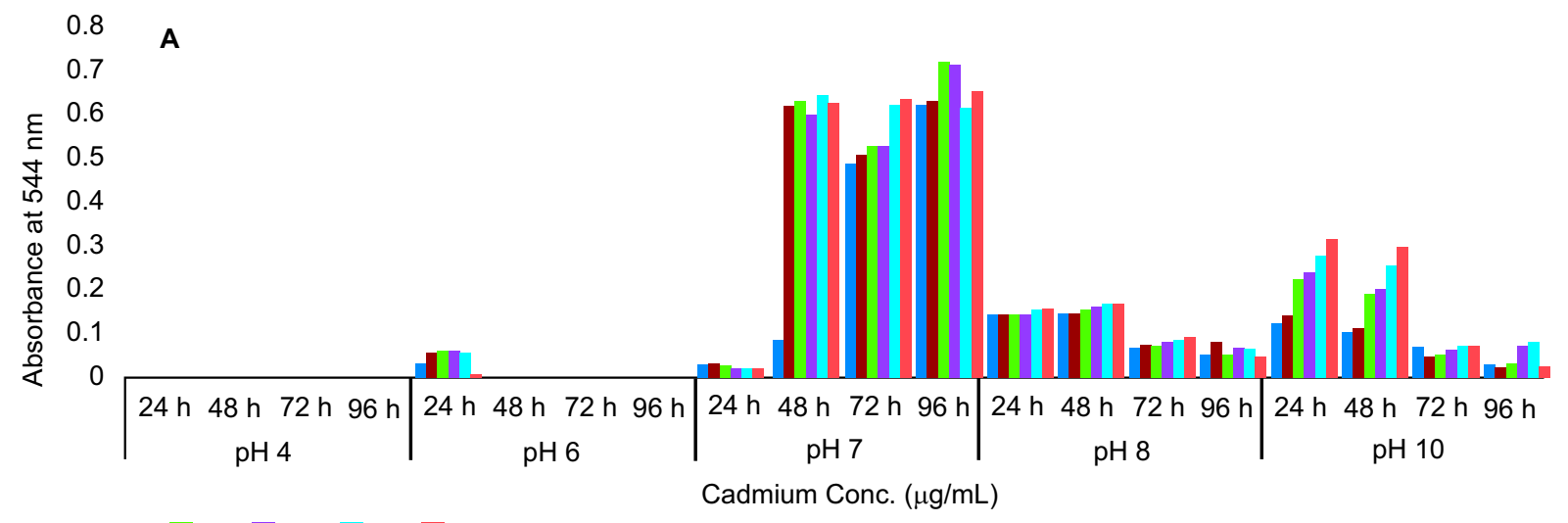

$50 \square 100 \square 150 \square 200 \square 250 \square 300$

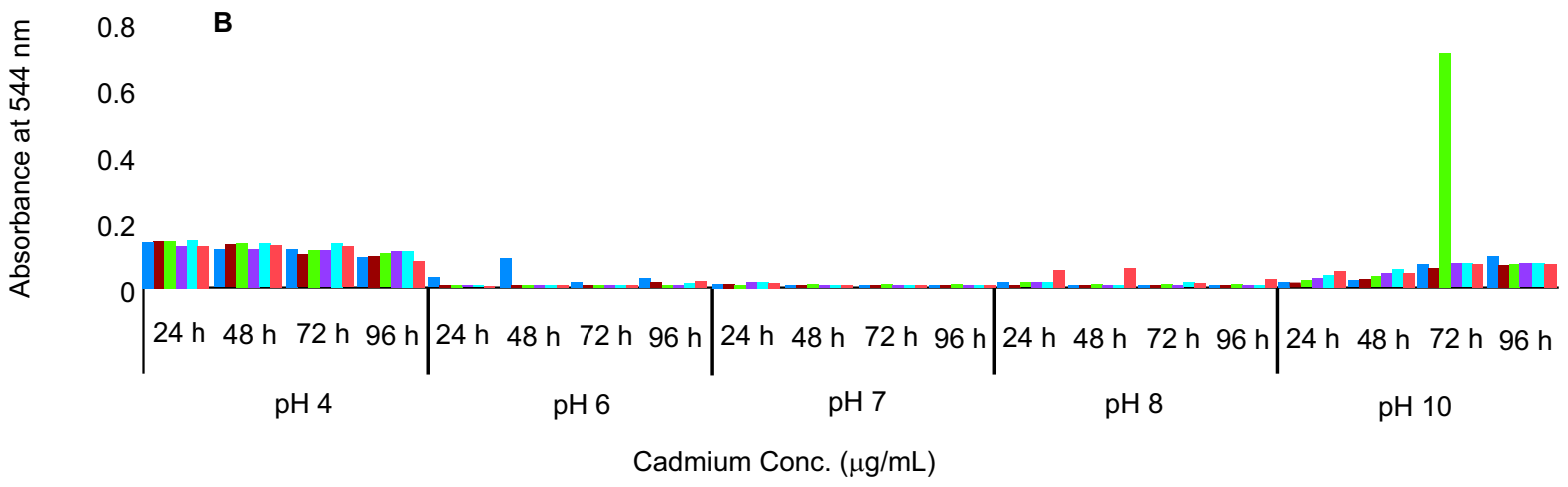

$50 \square 100 \square 150 \square 200 \square 250 \square 300$

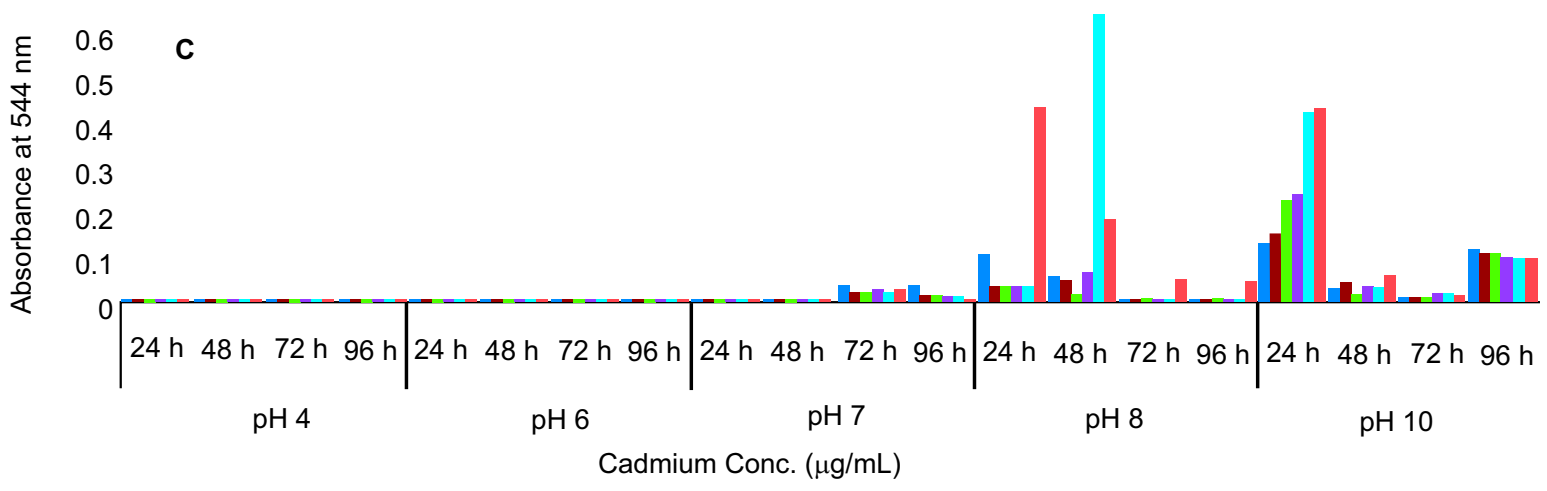

$50 \square 100 \square 150 \square 200 \square 250 \square 300$

Fig. 1. Bioaccumulation of cadmium concentrations by bacterial isolates at various $\mathrm{pH}$ and incubation periods. A) E. luteus, B) S. aureus, C) E. coli.

microbes (Fig. 1). S. aureus showed average results for absorbance of $\mathrm{Cd}(\mathrm{II})$ at $\mathrm{pH} 4$, but the absorbance capacity increased with increase in incubatory period. Basic $\mathrm{pH}$ 10 and acidic $\mathrm{pH} 4$ seemed to be very ineffective for the $S$. aureus to absorb Cd(II) metal (Fig. 1).
Cr(IV) bioaccumulation by $\boldsymbol{E}$. luteus. At pH $4 E$. luteus showed almost $100 \%$ absorbance capacity for $\mathrm{Cr}(\mathrm{IV})$ for all metal concentrations after $24 \mathrm{~h}$ of incubation but the absorbance ability was decreased gradually along with increase in incubation after each 


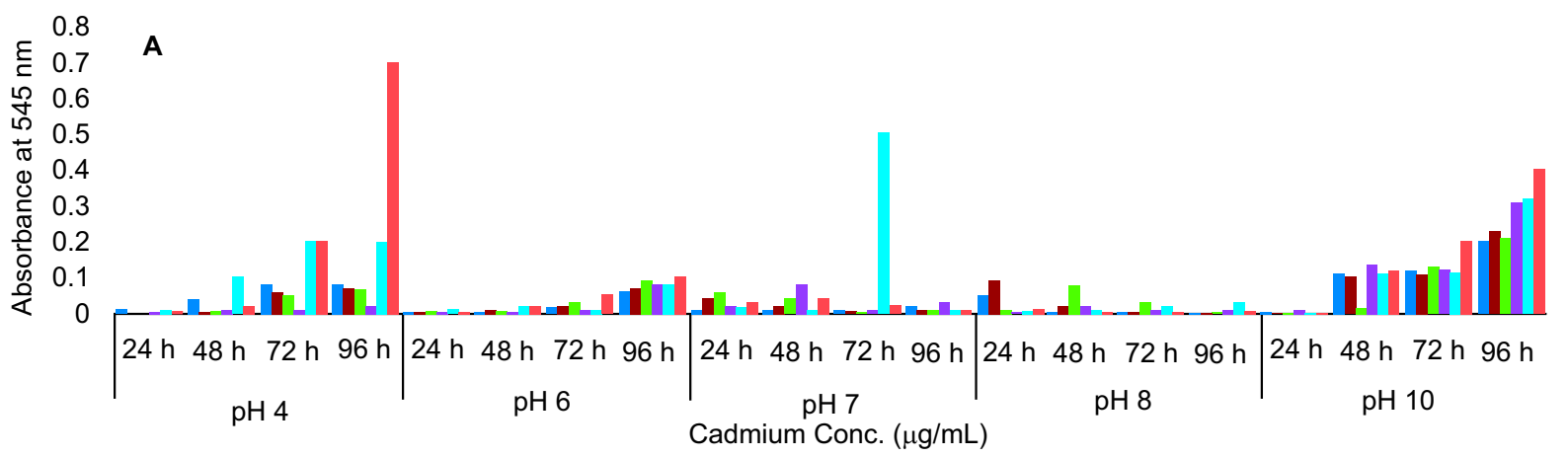

$50 \square 100 \square 150 \square 200 \square 250 \square 300$

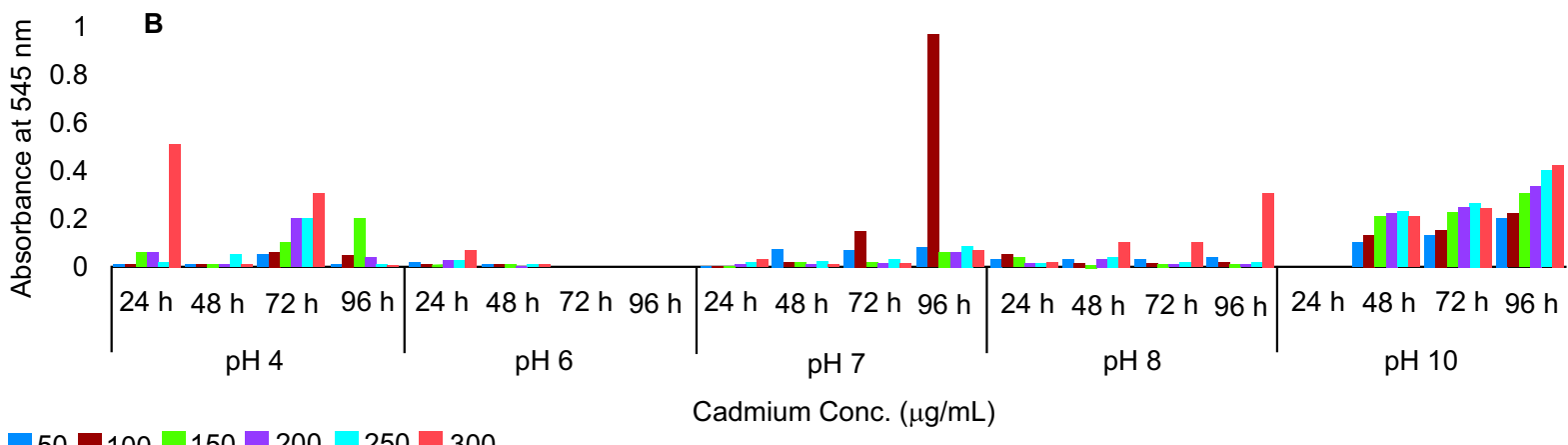

$50 \square 100 \square 150 \square 200 \square 250 \square 300$

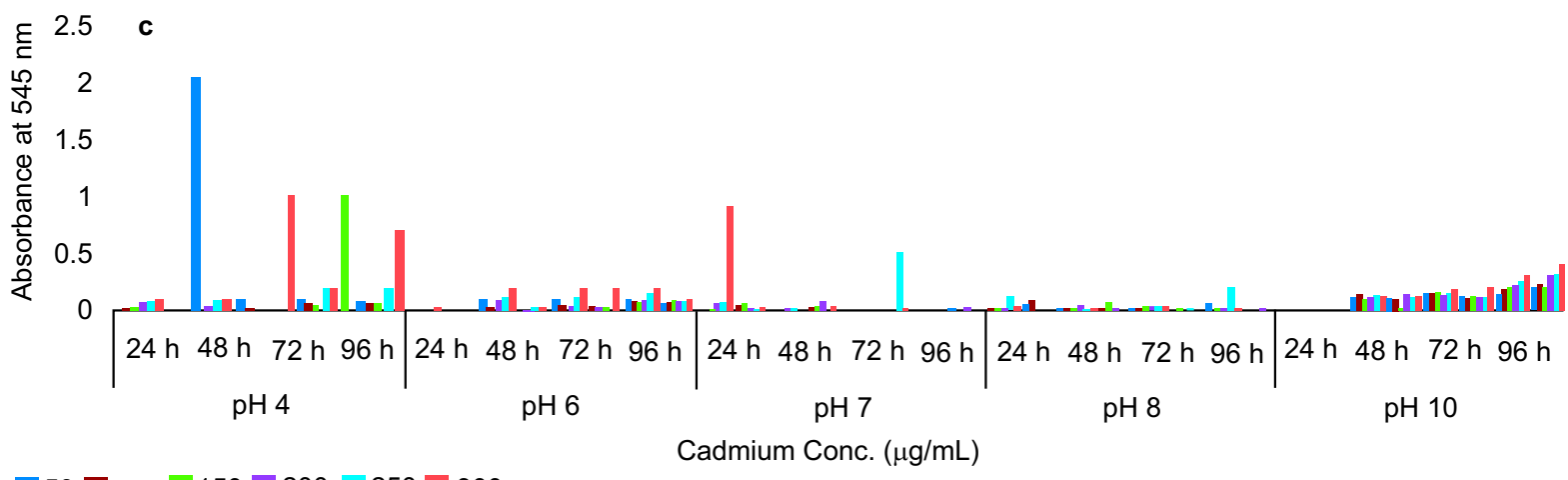

Fig. 2. Bioaccumulation of chromium concentrations by bacterial isolates at various $\mathrm{pH}$ and incubation periods. A) E. luteus, A) S. aureus, C) E. coli.

$24 \mathrm{~h}$ and finally the capacity decreased much after 96 h (Fig. 2). At pH 6, E. luteus showed gradual decrease in absorbance capacity for $\mathrm{Cr}(\mathrm{IV})$ metal concentrations with increase in incubatory period i.e., after each $24 \mathrm{~h}$ of incubation. At $\mathrm{pH} 7$, metal concentration in media showed a little decrease after $48 \mathrm{~h}$ but after $72 \mathrm{~h}$ $E$. luteus showed high absorbance capacity showing decrease in metal concentration but after 96 h capacity again decreased. At basic $\mathrm{pH} 8$, E. luteus showed good absorbance capacity after each $24 \mathrm{~h}$ of incubation. At high basic $\mathrm{pH} 10$ microbe showed decrease in absorbance capacity after each $24 \mathrm{~h}$ of incubation. After $24 \mathrm{~h}$ E. luteus absorbed $100 \%$ of each metal concentration except 50 and $200 \mu \mathrm{g} / \mathrm{mL}$.

Cr(IV) bioaccumulation by $\boldsymbol{E}$ coli. Escherichia coli absorbance activity for $\mathrm{Cr}(\mathrm{IV})$ metal concentration showed good activity after $24 \mathrm{~h}$ of incubation at $\mathrm{pH} 4$. At acidic $\mathrm{pH} 6$, E. coli showed near to $100 \%$ absorbance at $24 \mathrm{~h}$ incubation but after that with increase in incubation the absorbance capacity of microbe decreased 
gradually. At $\mathrm{pH} 7$, E. coli showed good absorbance even after $24 \mathrm{~h}$ of incubation and this capacity increased with increase in incubatory period. After $96 \mathrm{~h}$ of incubation the capacity remained $100 \%$ while at others like 48 and $72 \mathrm{~h}$ the capacity remained close to $100 \%$. Another effect seen was that the absorbance capacity was decreased with increase in concentration of metal i.e., from 50 to $250 \mu \mathrm{g} / \mathrm{mL}$. At highest concentration i.e., $300 \mu \mathrm{g} / \mathrm{mL}$ the microbe showed maximum absorbance that remained close to $100 \%$ at last two incubatory periods (Fig. 2). At pH 8, microbe showed good absorbance capacity after $24 \mathrm{~h}$ of incubation but this capacity was decreased gradually with increase in incubation. At high basic $\mathrm{pH} 10$, E. coli showed $100 \%$ absorbance after $24 \mathrm{~h}$ of incubation. But after further incubation, the capacity of metal absorbance decreased gradually.

$\mathbf{C r}(\mathrm{IV})$ bioaccumulation by $\boldsymbol{S}$. aureus. Staphylococcus aureus at acidic $\mathrm{pH} 4$ showed best absorbance capacity after $48 \mathrm{~h}$ of incubation (Fig. 2). After some incubations metal concentration showed negative impact on absorbance e.g., after 24, 72 and $96 \mathrm{~h}$ of incubation. At neutral $\mathrm{pH} S$. aureus showed maximum capacity to absorb Cr(IV) metal upto 72 of incubations but decline absorbance was recorded after $96 \mathrm{~h}$. Metal concentration had no clear effect on absorbance. At pH 6, S. aureus showed good absorbance activity after $24 \mathrm{~h}$ of incubation. S. aureus showed near to $100 \%$ absorbance capacity for the concentrations from 50 to $200 \mu \mathrm{g} / \mathrm{mL}$ but for $250 \mu \mathrm{g} / \mathrm{mL}$ and $300 \mu \mathrm{g} / \mathrm{mL}$ the capacity was decreased. After further incubation of 48, 72 and $96 \mathrm{~h}$, the capacity of metal absorbance of $S$. aureus decreased gradually (Fig. 2). At basic $\mathrm{pH} 8$ after $24 \mathrm{~h}$ incubation the estimated capacity of absorbance was good but maximum absorbance capacity was seen after $48 \mathrm{~h}$ incubation. The maximum capacity of absorbance of $S$. aureus at basic $\mathrm{pH} 10$ was seen after $24 \mathrm{~h}$ of incubation. After that the capacity decreased with increase in incubation i.e., 48, 72 and $96 \mathrm{~h}$ of incubation (Fig. 2). Increase in metal concentration gradually decreased the absorbance of metal.

When metals are dissolved in huge volumes at relatively low concentrations, metal removing technologies such as chemical precipitation, ion exchange, evaporation floatation and filtration become generally ineffective (e.g., less than $100 \mathrm{mg} / \mathrm{L}$ ) (Patterson, 1985). The research is for efficient and particularly cost-effective remedies (Blöcher et al., 2003; Volesky, 2001). Results of this study demonstrated that the biomass concentration strongly affected the amount of metal removed from aqueous solution. Moreover, as the biomass concentration rises, the maximum biosorption capacity drops, indicating poorer biomass utilisation. It shows that the sorption of metals is more correctly described by more than one model. In recent research, the same effect was observed in most of the results of metal absorbance, that the increase in metal concentration caused decrease in absorbance of metal, such as $\mathrm{Cd}(\mathrm{II})$ absorbance by E. luteus at $\mathrm{pH} 7,8,10$, by $E$. coli at $\mathrm{pH} 8$, and by $S$. aureus at $\mathrm{pH} 4,8,10$ and for $\mathrm{Cr}(\mathrm{IV}), S$. aureus at $\mathrm{pH}$

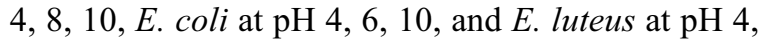
6 , and 10. In general, E. luteus seemed to be effective biosorbent at acidic pH 6 for $\mathrm{Cr}(\mathrm{IV})$ metal, while at basic $\mathrm{pH} 10$, showed minimum absorbance. E. coli also absorbed significant quantity of $\mathrm{Cr}(\mathrm{IV})$ metal in acidic $\mathrm{pH}$, while at basic $\mathrm{pH}$, the absorbance capacity decreased, at $\mathrm{pH} 7$, the microbe remained active absorbent. In case of $S$. aureus $\mathrm{pH} \mathrm{6,7}$ and 8 was favourable to absorb $\mathrm{Cr}(\mathrm{IV})$.

From bioaacumulation assay it was revealed that maximum biosorption was recorded after $24 \mathrm{~h}$. It means that exponential phase of microbial growth is very crucial for bioaccumulation of heavy metals. At this phase maximum absorbance could be possible due to less biomass of microbes. Our findings are consistent wih Abdel Aty et al. (2013), who reported that biosorption of metals was rapid in the first 20 min then was gradually increased till the equilibrium attained at 60 and 90 min for $\mathrm{Cd}$ and $\mathrm{Pb}$, respectively and the biosorption became almost constant thereafter. It was observed that when heavy metal concentration was more used, E. luteus showed sensitivity whereas resistant at $50 \mu \mathrm{g} / \mathrm{mL}$. E. luteus showed biosorption of Cr(IV) when concentration is increased upto $200-300 \mu \mathrm{g} / \mathrm{mL}$ at $\mathrm{pH} 10$ but greater absoption was measured at $\mathrm{pH} 6$, 7 and 8. It shows that both dead and live biomass was used for the $\mathrm{Cr}(\mathrm{IV})$ biosorption. Similar results were recorded for $\mathrm{Cd}$ (II) and $\mathrm{Pb}$ (II) onto A. sphaerica biomass. It may be carried out chemically via involving valence forces through sharing or exchange of electrons between sorbent and sorbate (Smith, 1981). Kefala et al. (1999) examined two specific strains of gram-positive Actinomycetes, living, non-living bacterial biomass for $\mathrm{Cd}(\mathrm{II})$ removal. They revealed that non-living biomass exhibited higher metal uptake. Our results are consistent with them that $S$. aureus and $E$. coli showed maximum absorption of $\mathrm{Cd}(\mathrm{II})$ as dead biomass. It is concluded that bacteria have the ability to absorb the metals within 
the cell body or on their cell wall and cell membrane as well.

Various types of biomasses such as bacteria, fungi, mushrooms, plants as well as chemically modified biosorbents were used for the removal of heavy metals (Kumar, 2014; Ghaima et al., 2013; Singh et al., 2012; Volesky, 1986). The attraction or affiliation of removal is dependent upon the chemical composition or structure of the organisms. The results show that for $\mathrm{Cd}(\mathrm{II})$ and $\mathrm{Cr}(\mathrm{IV})$ removal both dead and live biomass could be used. Chemical composition play vital role in heavy metal affiliation for removal from waste materials e.g., the overexpression of metallothioneins result in enhanced metal accumulation which provide an excellent strategy for the development of microbial based biosorbents for the remediation of metal contamination (Pazirandeh et al., 1995). Similarly, the expression of proteins on the surface of bacterial cell provides an inexpensive and affinity adsorbents.

\section{Conclusion}

It was concluded that optimisation of exponential phase of microbial growth, $\mathrm{pH}$ of media, incubation period, attraction between sorbent and sorbate and biomass (dead or alive) are important for biosorption process. More research is needed to clarify the impact of heavy metals on cellular structure and which part or organelle is efficient absorber for heavy metals.

\section{Acknowledgement}

Authors are thankful to Department of Zoology, University of Azad Jammu and Kashmir, Pakistan for financial support to carry out this research work.

\section{References}

Abdel -Aty, A. M., Ammar, N. S., Abdul Gaffar, H. H., Ali, R. K. 2013. Biosorption of cadmium and lead from aqueous solution by fresh water alga Anabaena sphaerica biomass. Journal of Advance Research, 4: 367-374.

Bhatnagar, A., Minocha, A.K. 2006. Conventional and non-conventional adsorbents for removal of pollutants from water-A review. Indian Journal of Chemical Technology, 13: 203-217.

Bishnoi, N.R., Pant, A., Garima, 2004. Biosorption of copper from aqueous solution using algal biomass. Journal of Scientific and Industrial Research, 63: 813-816.
Blöcher, C., Dorda, J., Mavrov, V., Chmiel, H., Lazaridis, N.K., Matis, K.A. 2003. Hybrid flotation-membrane filtration process for the removal of heavy metal ions from wastewater. Water Research, 37: 40184026.

Brierley, J.A. 1990. Production and application of a Bacillus- based product for use in metals biosorption. In: Biosorption of Heavy Metals, B. Volesky (ed.), pp. 305-312. CRC Press, Boca Raton, FL, USA.

Cheesbrough, M. 2002. District Laboratory Practice in Tropical Countries (Part II). pp. 40-56, Tropical Health Technology Publishers, Great Britain.

Collins, C.H., Lyne, P.M., Grange, J.M. 1999. Collin's and Lyne's Microbiological Methods. pp. 213-221, $7^{\text {th }}$ edition, Butterworth-Heinemann, Oxford, UK.

Collins, C.H., Lyne, P.M., Grange, G.M. 1989. Microbiological Methods. pp. 56-66, $6^{\text {th }}$ edition, Butterworth, London, UK.

Costa, M. 2003. Potential hazards of hexavalent chromate in our drinking water. Toxicology and Applied Pharmacology, 188: 1-5.

Elekwachi, C.O., Andresen, J., Hodgman, T.C. 2014. Global use of bioremediation technologies for decontamination of ecosystems. Journal of Bioremediation and Biodegradation, 5: 1-9.

Fu, Y., Viraraghavan, T. 2002. Removal of congo red from an aqueous solution by fungus Aspergillus niger. Advances in Environmental Research, 7: 239-247.

Fu, Y., Viraraghavan, T. 2000. Removal of a dye from an aqueous solution by the fungus Aspergillus niger. Water Quality Research Journal of Canada, 35: $95-111$.

Ghaima, K. K., Al Draghi, W. A., Lateef, N. S. 2013. Study the heavy metals tolerance, biosorption and antibiotic resistance of Bacillus cereus isolated from diesel fuel polluted soil. International Journal of Biological and Pharmaceutical Research, 4: 502-506.

Hammer, K.A., Carson, C.F., Riley, T.V. 1999. Antimicrobial activity of essential oils and other plant extracts. Journal of Applied Microbiology, 86: $985-990$.

Ismael, R., Rodriguez, X., Gutierrez, C., Moctezuma, M.D.G. 2004. Biosorption of chromium (VI) from aqueous solutions onto fungal biomass. Bioinorganic Chemistry and Applications, 2: 1-7.

Jagessar, R.C., Mars, A., Gones, G. 2008. Selective antimicrobial properties of Phyllanthus acidus leaf 
extract against Candida albican, Escherichia coli and Staphylococcus aureus using disc diffusion and agar well diffusion, streak plate and a dilution method. Journal of Natural Sciences, 6: 24-38.

Jomova, K., Valko, M. 2011. Advances in metal-induced oxidative stress and human disease. Toxicology, 283: $65-87$.

Joshi, P.K., Swarup, A., Singh, N. 2011. Bioremediation of heavy metals in liquid media through fungi isolated from contaminated sources. Indian Journal of Microbiology, 51: 482-487.

Kefala, M.I., Zouboulis, A.I., Matis, K.A. 1999. Biosorption of cadmium ions by Actinomycetes and separation by flotation. Environmental Pollution, 104: 283-293.

Kocberber, N., Donmez, G. 2007. Chromium (VI) bioaccumulation capacities of adapted mixed cultures isolated from industrial saline wastewaters. Bioresource Technology, 98: 2178-2183.

Kratchovil, D., Volesky, B. 1998. Advances in the biosorption of heavy metals. Trends in Biotechnology, 16: $291-300$.

Kumar, R., Singh, P., Dhir, B., Sharma, A.K., Mehta, D. 2014 Potential of some fungal and bacterial species in bioremediation of heavy metals. Journal of Nuclear Physics, Material Sciences, Radiation and Applications, 1: 213-223.

Li, H., Lin, Y., Guan, W., Chang, J., Xu, L., Wei, G. 2010. Biosorption of $\mathrm{Zn}$ (II) by live and dead cells of Streptomyces ciscaucasicus strain CCNWHX 72-14. Journal of Hazardous Materials, 179: 151159.

Meleleo, D., Notarachille, G., Mecello, S. 2010. Choline Modulation of the a $\beta$ P1-40 Channel Reconstituted into a model lipid membrane. International Journal of Alzheimer's Disease, 2010: 12 pp., http: // dx. doi. org/10 4061/2010 Aticle Id 752804.

Navarro, A., Weissbach, S., Faria, M. 2012. ABCB and $\mathrm{ABCC}$ transporter homologs are expressed and active in larvae and adults of zebra mussel and induced by chemical stress. Aquatic Toxicology, 15: 122-123, 144-152.

Patterson, J.W. 1985. Industrial Wastewater Treatment
Technology, pp.53-393, $2^{\text {nd }}$ edition, Butterworth Publication, Stoneham, USA.

Pazirandeh, M., Chrisey, L., Mauro, J., Campbell, J., Gaber, B. 1995. Expression of the Neurospora crassa metallothionein gene in Escherichia coli and its effect on heavy-metal uptake. Applied Microbiology and Biotechnology, 43: 1112-1117.

Prescott, M.L., Harley, J., Donald, P., Klein, A. 1999. Antimicrobial chemotherapy. In: Microbiology, 325 pp., $2^{\text {nd }}$ edition, C. Brown Publishers, U.S.A.

Saraswat, S., Rai, J.P.N. 2010. Heavy metal adsorption from aqueous solution using Eichhornia crassipes dead biomass. International Journal of Mineral Process, 94: 203-206.

Seeley, H.W., Vandemark, P.J., Lee, J.J. 2001. Microbes in Action: A Laboratory Manual of Microbiology, pp. 57-130, $4^{\text {th }}$ edition, W.H. Freeman and Co., New York, USA.

Shumate, S.E., Stranberg, G.W. 1985. Accumulation of metal by microbial cells. In: Comprehensive Biotechnology, M. M. Young et al., (eds.), pp.235247, Pergamon Press, New York, USA.

Singh, U., Singh, B.P., Singh, K.K. 2012. Lead removal from aqueous solutions by Bacillus subtilis. Journal of Chemical and Pharmaceutical Research, 4: 2242-2249.

Smith, E.H. 1996. Uptake of heavy metals in batch systems by a recycled iron-bearing material. Water Research, 30: 2424-2434.

Smith, J.M. 1981. Chemical Engineering Kinetics, pp. 310-322, $3^{\text {rd }}$ edition, New York, McGraw-Hill, USA.

Solecka, J., Zajko, J., Postek, M., Rajnisz, A. 2012. Biologically active secondary metabolites from Actinomycetes. Central European Journal of Biology, 7: 373-390.

Tokar, E.J., Benbrahim-Tallaa, L., Waalkes, M.P. 2011. Metal ions in human cancer development. Metal Ions in Life Science, 8: 375-401.

Volesky, B. 2001. Detoxification of metal-bearing effluents: biosorption for the next century. Hydrometallurgy, 59: 203-216.

Volesky, B. 1986. Biosorbent materials. Biotechnology and Bioengineering Symposium, 16: 121-126. 